Towards a Transdiciplinary Systemic Approach to National Heritage-Based Learning. Curricular Insights into the Romanian Art Education Reform in the Glocal Transformative Age

Mihaela-Gabriela Cosma Oneţ 


\title{
Towards a Transdiciplinary Systemic Approach to National Heritage-Based Learning. Curricular Insights into the Romanian Art Education Reform in the Glocal Transformative Age
}

\author{
Mihaela-Gabriela Cosma Oneț ${ }^{\mathrm{a}^{*}}$
}

\begin{abstract}
${ }^{a}$ Doctoral School "European Dynamics (DynamE)", Faculty of Humanities and Social Sciences. European Prospects, University of Strasbourg, 4 Blaise Pascal Street, Strasbourg, 67081, France

${ }^{a}$ Doctoral School "Educational, Reflection, Development", Faculty of Psychology and Educational Sciences, Babeș-Bolyai University Cluj-Napoca, Romania, 7 Sindicatelor Street, 400029, Romania

*Corresponding author: mihaela-gabriela.onet@etu.unistra.fr
\end{abstract}

\section{Abstract}

Keywords:

National Heritage learning; transdiciplinarity; curriculum planning; transformative learning; systemic approach; glocal; arts and culture experiences.
The aporia of the collapsology threats in the contemporary era of globalization, as well as our need for psychosocial-ecological resilience and well-being have shown the crucial imperative to improve education. Thus, it is through innovating the curriculum design and its intimate features that humanity will be able to restore the world's health and wealth. Consequently, the author stresses an original approach to curricula renewal in order to bridge the gap between school and society while building students' 21st century competencies. Given the challenges of today's technological and glocal era, new transformative learning pathways have been established by considering transdiciplinarity as theoretical reference. Hence, this study develops a theoretical systemic model to design a national heritage-based learning curriculum, which underpins collaborative and experiential learning. Likewise, through a transferable competency-based curriculum on national heritage, students undergo a transpersonal well-being as a holistic character-building process.

\section{Zusammenfasung}

\section{Schlüsselworte:}

nationales Erbe Lernen;

Transdisziplinarität;

Bildungsplanung; transformative Lernwege; systemische Ansatz;

glokal; Kunst und Kultur Erleben.
Die Aporie der kollapsologischen Bedrohungen in der heutigen Zeit der Globalisierung sowie unser Bedürfnis nach psychosozial-ökologischer Widerstandsfähigkeit und Wohlbefinden haben gezeigt, wie entscheidend wichtig es ist, die Bildung zu verbessern. So kann die Menschheit nur durch eine innovative Gestaltung des Lehrplans und seiner intimen Merkmale die Gesundheit und den Wohlstand der Welt sichern. Infolgedessen betont der Autor einen originellen Ansatz, zur Erneuerung der Lehrpläne, um die Kluft zwischen Schule und Gesellschaft zu überbrücken und gleichzeitig die Kompetenzen der Schüler für das 21. Jahrhundert zu stärken. Angesichts der Herausforderungen der heutigen technologischen und glokalen Ära wurden neue transformative Lernwege geschaffen, indem Transdisziplinarität als theoretische Referenz berücksichtigt wurde. Daher entwickelt diese Studie ein theoretisches, systemisches Modell, um ein nationales, auf dem kulturellen Erbe basierendes Lerncurriculum zu entwerfen, das kollaboratives und erfahrungsorientiertes Lernen. Ebenso erfahren die Schüler durch einen übertragbaren kompetenzbasierten Lehrplan zum nationalen Erbe ein transpersonales Wohlbefinden als ganzheitlichen Prozess der Charakterbildung.

\section{Introduction}

Our contemporary society is under the sway of technology and digitization. It is well-known that we are living both in the Anthropocene era (Steffen, Crutzen \& McNeil, 2007) and in The Fourth Industrial Revolution epoch (Schwab, 2015). Undoubtedly, the world has opened up but, unfortunately, climate, social and medical crises are continuously damaging our planet and destroying the humanity.

In this light, educational institutions have to undergo major restructuring, they "have to reinvent themselves" (Cardoso Espinosa, 2021, Preface, xiv), and to enable students to be highly skilled. Hence, contemporary education will be able to cope with the new existing $21^{\text {st }}$ century societal shifts while promoting students "active involvement in a formative learning process" (Bocoş \& Jucan, 2019, p. 25).

Accordingly, this paper proposes an innovative holistic theoretical model of heritage-based learning in the Romanian art education, and especially in the case of fine arts high schools. This planning of curriculum learning pathways promotes both experiential artbased and cross-curricular school subjects, as well as 
cultural learning activities based upon heritage education. These are the key topics that have been developed in this study.

From this standpoint, it is important to implement a new heritage learning planning as a curriculum renewal in the Romanian schools of arts. Moreover, one needs to design a new curriculum planning, whose contents and goals may "apply territorially or at a specific school level according to its own educational needs" (Bocoș, 2001, p. 100). In fact, this is a glocal learning approach to globality. Given that learners do collaborative work in experiential formal and nonformal learning contexts (Dewey, 1963), they learn about the common heritage of humanity and they reflect upon the destiny of the contemporary nations (Choay, 2009).

\section{Theoretical foundations and epistemological insights}

The pivotal issue addressed by this paper is a possible new societal shift in art education. From this standpoint, our specific research question is how to conceive an original theoretical systemic model of an Intangible Cultural Heritage learning in the curriculum of fine arts high schools, whose implementation will develop in our students the $21^{\text {st }}$ century crosscurricular skills for lifelong education. Furthermore, our study entails new transformative experiential curricular learning pathways, which are supposed to help learners reach their transpersonal well-being as a holistic character-building process inside and outside the classroom.

With this in mind, these major educational goals will be carried on through an epistemological approach. Thus, this paper yields insights into the scientific theoretical framework of our study as a scholarly consensus on promoting progressive New Pedagogies in order that students can reach transformative competencies (OCED, 2020), which are mindful learning outputs. Moreover, experiencing a cultural transdisciplinary education based on National Heritage studying at school inevitably entails a raise of well-being in the school environment, as a revolutionary proposal of a transformative Paideia plan (Adler, 1984).

On the basis of these scientific backgrounds, the author's standalone theoretical modelling-based approach to design an innovative heritage-based curriculum will be featured. Therefore, while both creative development of a complex systemic- interactionist models (Andronache, Bocoş \& Neculau, 2014) and didactic analogies are developed, effective heritage learning is being targeted (Glava, 2009; Glava \& Glava, 2011) in the context of art education in the Romanian secondary schools of fine arts.

In this light, this paper aims at scholarly innovating the educational insights into the national heritage study at school from a transdisciplinary perspective. This new vision of developing the curriculum planning also focuses on shaping societal adaptative competencies (Bocoş, 2010).

2.1. Transdisciplinarity in the heritage-based learning curriculum: A holistic approach to the reality of life

Owing to its features, transdisciplinary transcends a simple school subject and goes between, across and beyond (Nicolescu, 1985) the academic disciplines by fusion of knowledge, methods and spirituality. Hence, self-transformation is involved in a trans relation with the four pillars of learning, e.g., learning, learning to do, learning to be, learning to live with others (Delors, 1996; Nicolescu, 1985, 1997; Gibbons, 1994; Ciolan, 2008) towards gaining "the sense of humanity" (Ionescu, 2010, p.17). Taking into account that transdisciplinarity in education means a superior level of integration (Nicolescu, 1996; Ciolan, 2008; Morin, 1999), which transcends multidisciplinarity, innovative learning-teaching-training and regulatory feed-back evaluation processes are prioritized. Accordingly, it is through conceiving and piloting a heritage-based learning programme, especially in fine arts high school, that teachers can highlight important "entering points" to innovation (Văideanu, 1988) in this cross-curricular learning context.

Contemporary school need a real strong change so as to prepare students to build trustful human relationships. Moreover, schools of arts have to enable learners to make the choice of the best career in the future. Not only have they to be well-prepared professionally speaking, but also to be resilient, ethical and human. Hence, there is a tremendous need for a heritage education based on humanistic cultural values. This is a complex learning process which promotes identity and alterity built on a national psychanalysis (Bourdieu \& Passeron,1964; Meirieu \& Develay, 1992).

As we know, the curriculum is the main structure of implementing the learning-teaching-training framework at school. The planning and the 
development of an appropriate curricula have to bridge the gap between school, politics and society, between the theory and the practice of education, between the formal, non-formal and informal learning contexts. Henceforth, this paper is a plea for the educational eternal need for change alongside the contemporary holistic societal shift. This challenge implies not only a transdisciplinary integrated approach of the National Heritage in the optional school curricula, but also a removing plan from the "closed" school spaces towards "the open spaces". It is through finding these new learning contexts that "relatively new situations" (Păun, 2017, p. 178) are built. They are innovative didactic gateways towards the collaborative perspectives of intangible cultural heritage learning, and real world-life learning paradigm. Consequently, it is highly recommended that a National Heritagebased learning curriculum underpins a transnational approach embedding all cultures. This curricular perspective entails to foster all students' knowledge, skills, positive attitudes.

Likewise, Intangible Cultural Heritage is perceived as an experiential artistic approach to the heritage, whose major power is to connect generations through both the beauty of art and the fascination of history (Choay, 2009). Furthermore, National Heritage in school curriculum can be a powerful key concept based on the sociocultural theory, which in fact meets the requirements of the Yin-Yang Curriculum vision framework (Twining, 2020).

Given the international community agreement to unite all forms of heritage under the holistic concept of Intangible Cultural Heritage (UNESCO, 2003), throughout this paper the terms of "Intangible Cultural Heritage", "heritage" and "national heritage" are used interchangeably to include collective tangible and intangible elements of specific cultural heritage.

\subsection{Going glocal: outlining the glocality through} the National Heritage learning modelling

According to Encyclopedia Britannica (2007) the concept of glocality was popularized by the sociologist Roland Robertson. However, Friedman's monetarist theory to "think global, act glocal" (Friedman, 1999, pp. 7-8) has become a transdisciplinary concept, which has been creatively endorsed by other sciences.

Apart from this, in the scholarly literature it is increasingly recognized that glocalization indicates that the growing importance of continental and global levels is occurring together with the increasing salience of local and regional levels. Glocalization appears alongside tendencies of heterogeneity and decentralization.

In this paper, glocality is seen as a new perspective of the paradigm shift of the worldwide globalization from a cultural and pedagogical perspective.

On the one hand, the intent is to plan and to promote a nonformal heritage learning process, which focuses in this curriculum on experiencing glocalization. Following the Garcia's (2020) vision of glocalization, the students of fine arts high schools will learn to interiorize National Heritage as a shaping of local spaces and identities both by globalized contacts and by local circumstances. Thus, glocality can be pedagogically put into practice through implementing a local curriculum learning, whose contents and goals may "apply territorially or at a specific school level according to its own educational needs" (Bocoș, 2001, p. 100).

On the other hand, it is necessary to take into account the power of art both to bring added value to national heritage and to keep its collective memory alive through valuable transmission. In this light, art is seen as an intimate way of thinking, the very essence of our societal identity (Somé, 2019).

Keeping this in mind, it is necessary to recognize at all educational levels the need of experiencing a shaping of local spaces and identities both by globalized contacts and by local circumstances (Encyclopedia Britannica, 2007). This is one of the most valuable way for Romanian and European learners to become aware of the unicity and universality of their cultures.

\subsection{A model of transformative and never-ending} learning curriculum design

There is a contemporary wind of change in education, as a result of the tremendous learning process need "to transform in order to be transformative" (Sterling, 2001, p. 19). From this perspective, transformative learning planning is an innovative approach to teaching-learning, where educators challenge learners to critically review relation to the world around them (Mezirov \& Tylor, 2010).

Given that developing character features follows a typical established process of re-building a strong personality (Chiş, 2014), a transformative learning scenario is carried out by our analytic heritage-based 
learning model. Hence, a creative trans-personality is supposed to be shaped not only through co-teaching, but also through teaching contextualization of cultural processes which are intertwined with best learning practice (Mezirov, 2012; Mizzi et al., 2017). Moreover, this transformative learning scenario also entails enhancing cultural identity and diversity (Jeannin, 2017). Given this panorama, this new heritage-based curricular planning underpins a collective trans-formation under the sign of heritage study. In fact, this is achievable through a large array of new disciplines, such as literature and old schools' heritage, the time dimension of the collective memory, aesthetic heritage, etc. (see Figure 1). Therefore, participants can learn how to develop strong relationships between their identity and the otherness, while mediating cultural conflicts or via "reflective thinking" (Dewey, 1963).

In addition, learners become aware of the need to preserve the nature as a precious element of heritage (Davallon, 2010). Consequently, they can also reframe their relationship with the environment, and to crystallize never-ending learning skills according to the theories of "transformation" and development (Mezirov, 2012).

\section{A mindset systemic approach to design the National Heritage-based school learning}

National Heritage is seen as a resource of territorial development at all levels of the society. It is obvious that its knowledge enhances the social participatory sustainability, via experiencing formal, informal and nonformal learning pathways (see Figure $1)$.

In this paper the concept of heritage is seen in the light of the stipulated regulations in the 2003 UNESCO's Convention for the Safeguarding of the Intangible Cultural Heritage. According to this document, the "intangible cultural heritage" embodies all cultural elements upon which communities unanimously agree to be part of their cultural heritage, Thus, along with non-tangible elements such as "practices, representations, expressions, knowledge, skills", there are also tangible elements of culture, e.g. "the instruments, objects, artefacts and cultural spaces associated therewith" (UNESCO, 2003, Art. 2), so as to be included in the Intangible Cultural Heritage. As we know, without the memory touch, heritage ends its important societal signification, and all cultural object, various landscapes, wildlife and natural resources have to be meaningful for communities in order to be acknowledged as part of National Heritage through an institutionalized heritagization process (Choay, 1992; Davallon, 2014; Bortolotto, 2011). On the other hand, modelling a $21^{\text {st }}$ century transdisciplinary heritage competency-based learning plan implies undoubtedly collaborative and experiential viewpoints, because its main purpose is to study in situ the psychological features of a nation, the heart and the spirit of a people (Negruţiu, 2005).

With this in mind, the author's original proposal to the existing epistemological background of both transdisciplinary and heritage education is built on the systemic model construct of a heritage-based learning curriculum in the context of fine arts high schools.

Accordingly, our mindsight model to design the National Heritage-based learning is seen as a systemicinteractionist mental mind mapping of the cross curricular planning phase. According to Ciolan (2008, p. 164), this is the first and the major "innovative driver" of the transdisciplinary curriculum building, a crucial premise for the further curriculum development processes. Furthermore, this learning model focuses on empowering students to empathically perceive vernacular or vehicular, both national and universal human mind and soul via experiencing "anthropology and philosophy of the sensibility" (Somé, 2017) as well.

The author's original proposal to the existing theory includes an outline of a systemic heritage-based learning curriculum planning to provide art schools pupils with the $21^{\text {st }}$ century long lasting transdisciplinary competencies. This flexible curriculum tool aims to also reach personal wellbeing, and planetary sustainability (OCED, 2020).

With regard to this, it is important for teachers to design creative transdisciplinary curricula shaped on heritage education, which can be piloted mainly in fine arts fine high schools, as a part of a new paradigm of the Progressive Education via collaborative and experiential learning (see Figure 1 below). Thus, it is through learning about heritage by taking an ethnological and anthropological approach in nonformal contexts that students can foster knowledge, skills and values in a differentiate and interiorized manner, while deepening common moral consciousness. Furthermore, it is likely that this heritage-based learning will promote complex learning styles and modern long life learning paradigms. These learning processes also stimulate the 
motivation for studying, as well as "the openness to positively react to any change" (Bocoş, 2001, p 105).

3.1. A theoretical systematic model of heritagebased learning in the contemporary fine arts high schools

The following pages will present an original use of the paradigm of models and analogies in educational sciences. Thus, this innovative paradigm is focused on fostering original formative didactic learning strategy by promoting "new desirable learning experiences" (Bocoş \& Jucan, 2019, p. 22) through a heritage-based curricular approach. It is well-known that a scientific modelling approach enhances effective learning (Glava, 2009; Glava \& Glava, 2011). It also helps teachers to create a meaningful "systemicinteractionist model" (Andronache, Bocoş \& Neculau, 2014) of a heritage competencies-based learning curriculum, which is life long-learning oriented. From an Intangible Cultural Heritage-based learning perspective, Figure 1, below, suggests that the students of fine arts high school can undergo transformative, collaborative and trans experiential learning processes through a transdisciplinary mixture of a large array of subjects taught in each Romanian school of arts.

Thus, Figure 1, below, is a powerful argument to promote transdiciplinarity by studying ethography, museology, geoculture, identity and otherness in Romanian artistic education. In this way, students could become resilient and reach the Nicolescu's Hidden Third as a transpersonal well-being through "understanding cultural differences" (Hall \& Hall, 1990).

While analyzing this conceptual learning model, the first level of our Intangible Cultural Heritage programme embodies an overview of the pedagogical mezzo level curriculum seen as "a complex, dynamic social phenomenon" (Bocoş, 2007, p.17). This is in line with the interactive-based, integrated fusion of school subjects into that of Intangible Cultural Heritage from a socio-cultural perspective.

The heritage-based teaching-training-learning process is shaped so as to include all transdisciplinary heritage elements, from a diachronic and synchronic perspective, as well as from a cultural artistic angle.

Moreover, this approach of heritage curriculum also focuses on studying natural heritage. In addition, there are various practical learning insights into both national and European heritage through ethnography and anthropology, as Figure 1 shows.

Generally speaking, this curriculum concept has also foreseen students' practical immersion in situ, i.e., into the richness of real local heritage trades. Thus, there will be opportunity for students to think about choosing a future career in the field of preserving or promoting heritage via practicing ancient or modern skilled jobs or ancestral craftsmanship. Therefore, students may as well give rise to the future National Heritage through creative artistic professional work for livelihoods, whom Adell (2016) metaphorically called "jobs inside heritage".

Figure 1. The Intangible Cultural Heritage learning in the contemporary school as a didactic model (Original work)




As shown in Figure 1 above, it is the Nicolescu's Hidden Third that is the main trans personal goal to be attained by all participants involved in this innovative cultural learning process, i.e., students and their educational partners. In addition, it becomes clear that this emotional effect is considered to be the peak learning performance, as well as a way to gain transformative, collaborative, long life lasting skills. These transdisciplinary heritage competencies are deemed to be main educational desiderata, and they can only be reached through a large array of transdisciplinary practical learning tools. In this light, this learning systemic model clearly promotes different embedded learning concepts and styles, as a starting point to further curricular processes of "the eightfold path of the curriculum" (Ciolan, 2008, p. 164). Thus, all these processes of this first curricular shaping phase - e.g., heritage contents, learning contexts, and goals perspectives - are interwoven under the holistic cupola of Intangible Cultural Heritage topic.

At the second level, there is the humanistic heritage learning dimension which is highlighted. Consequently, strong relationships based on both identity and diversity learning are built between all participants in the heritage learning process. Thus, participative, collaborative and experiential strong bonds between the members of the educational classic triangle (Bocoş, 2008, p. 25) are reset through artdoing and through preserving National Heritage. Moreover, these relationships will be also strengthened between all participants who take part in learning about heritage in various informal and nonformal learning contexts, i.e., heritage professional guests.

Furthermore, as shown in Figure 1, we lay great weight on strengthening the role of nonformal and informal artistic cultural contexts so as to make students gain new transdisciplinary skills. Thus, transformative new competencies are supposed to be developed via the Intangible Cultural Heritage curriculum shaping, which becomes resourceful for both educational and economical sustainability through experiencing (Dewey, 1963) its growth and impact.

At the third level, by examining the complexity of the multilevel rapports between heritage and the territorial level of the learning process, multiple glocal insights into the major heritage components have been foreseen. Consequently, it is vital to adapt the curriculum content and learning strategies as a global stream which is glocally transformed into a local culture. However, as Boyd \& Richerson (2009) stated, this new glocal culture will be reincorporated into a newer global one, by following a constant cycle movement.

On the upper level of the heritage learning processes of our transdisciplinary integrated curriculum framework, we explore art diversity and power of positioning as catalysts for learning about culture and civilization. According to Figure 1, our systemic learning process develops a transversal approach to heritage conservation and restoration in terms of esthetic learning of the heritage of otherness, for instance. The latter is seen from an anthropological point of view as a powerful tool for learning heritage. As Somé (2019) said, the anthropology of art has to be perceived in fact as a cultural and civilizational bond between different people all over the world, as a benchmark of the universality of the human being. Thus, heritage learning promotes transdisciplinary through valorizing paradigms and key concepts as identity, national, glocal and European treasures, agency and participation. Moreover, this heritage learning pathway design aims at "educating the students' feelings and characters" (Ionescu, 2010, p.21), as a backbone of generating well-being at school, which is hidden in the Nicolescu's Third Level of Reality (1996). In our view, this is the only way to outreach the educational crisis and our Planetarium Era's (Morin, 1999) challenges.

\section{Conclusions}

A few interesting conclusions emerge from an overview of this background paper. As we know, both practitioners and theoreticians have to keep students' learning profile development in mind, and its usefulness across the lifespan. Thus, this article details a new approach to cross-curricular learning of national heritage in the context of Romanian fine arts high schools, which goes beyond the disciplines (Nicolescu, 1985, 1996).

The main goal of our curriculum development planning is not only to show how to bring school closer to the society, but also to make learning a better place through building a heritage learning organization group. Thus, students' motivation and joy of learning are visibly strengthened by various non formal and informal heritage learning contexts (Hattie, 2009). 
Undoubtedly, preserving National Heritage, experiencing transdiciplinarity and glocality through learning about our cultural, material or scientific richness, about the values of otherness are precious conceptual transformative learning frameworks. One can say that this heritage learning curricular pathway helps young Romanian future artists to acquire the lifelong learning skills, to choose a future career, to adapt to the glocalized society through collaboration and empathy. Finally, students may be able to build "outstanding societies" (Somé \& Roux, 2017), and to become aware of being "part of this Reality that changes due to our thoughts, feelings and actions" (Nicolescu, 2012, p. 717).

\section{Acknowledgments}

First and foremost, the author's special thanks go to her Professor and Romanian Thesis Supervisor, Mrs. Muşata-Dacia Bocoş, for her creative suggestions, and for her unconditional emotional support and trust. The author wishes to acknowledge her valuable contributions regarding the proofreading of my article, for her meticulous attention to detail.

\section{Authors note:}

Mihaela-Gabriela Cosma Oneț is an international $\mathrm{PhD}$ student in the field of Educational Science, Social Sciences and European Perspectives. She is currently developing an international jointlysupervised thesis between the University of Strasbourg, France and Babeş-Bolyai University, Cluj-Napoca, Romania. As a teacher at R. Ladea Fine Arts High School in Cluj-Napoca, Romania, her scientific research addresses the epistemological background of Heritage Education and its impact on transdisciplinary students' learning outcomes. Mrs. Oneţ also coordinated an intercultural Erasmus+ project on National Heritage and she is involved in the activity of the Erasmus+ programmes hub at school. Owing to her specialization in Geomorphology, Educational and Tourism Management, her scientific research and interests are focused not only on transdisciplinary learning activities about National Heritage, but also on complex partnerships with French high schools or local, regional and national NGOs, through volunteering.

\section{References}

Adell, N. (2016). Le sens de la visite. In Le tournant patrimonial: Mutations contemporaines des métiers $d u$ patrimoine Hottin, C. \& Voisenat, C. (Eds.) Paris: Maison des Sciences de l'Homme.
Adler, M.J., \& the Paideia Group. (1984). The Paideia program: An educational syllabus. New York: Macmillan.

Andronache, D., Bocoş, M. \& Neculau, B.C. (2014). A systemic-interactionist model to design a competencybased curriculum. Procedia-Social and Behavioral Sciences.180 (2015), 715-721. London: Elsevier. Available at: www.sciencedirect.com ScienceDirect1877-0428 (accessed at 12.09.2020).

Bocoş, M. (2001). Curriculumul şcolar şi aspectele sale esenţiale. In M. Ionescu \& I. Radu (Eds.) Didactica modernă. Ediţia a II-a, revizuită. Cluj-Napoca: Editura Dacia.

Bocoş M. (2007). Didactica disciplinelor pedagogice. Un cadru constructivist. Ediţia a II-a, revăzută. Piteşti: Editura Paralela 45.

Bocoş, M. \& Jucan, D. (2019). Fundamentele pedagogiei. Teoria şi metodologia curriculumului. Repere şi instrumente didactice pentru formarea profesorilor. Ediţia a IV-a. Piteşti: Editura Paralela 45.

Bocoş, M. (2010). Formarea didactică la Universitatea Babeş-Bolyai. Semnificări şi resemnificări în diacronie. In Ionescu, M. (Ed.) Şcoala clujeană de pedagogie - 90 de ani. Cluj-Napoca: Casa Cărţii de Ştiinţă.

Bortolotto, C. (Ed.) (2011). Le Patrimoine culturel immatériel. Enjeux d'une nouvelle catégorie. Paris: Maison des Sciences de l'Homme.

Bourdieu, P. \& Passeron, J.C. (1970). La reproduction. Éléments pour une théorie du système d'enseignement. Paris: Éditions de Minuit.

Cilers, P. \& Nicolescu, B. (2012) Complexity and transdisciplinarity - Discontinuity levels of Reality and the Hidden Third. Futures, 44(8), pp. 711-718. Available at: https://www.sciencedirect.com/journal/futures/vol/44/is sue/8 (accessed at 12.12.2020).

Boyd, R. \& Richerson, P.J. (2009). Culture and the evolution of human cooperation. The Royal Society Publishing, Vol. 364, Issue 1533:3281-3288. Available at: https://royalsocietypublishing.org/doi/abs/10.1098/rstb. 2009.0134 (accessed at 13.12.2020).

Cardoso Espinosa, E.O. (Ed.) (2021). Developing Mathematical Literacy in the Context of the Fourth Industrial Revolution. Santo Tomás: Instituto Politécnico Nacional.

Chiş, V. (2014). Fundamentele pedagogiei: repere tematice pentru studenţi şi profesori. Ediţie bilingvă. Cluj-Napoca: Editura Eikon.

Choay, F. (1992). L'Allégorie du patrimoine. Paris: Seuil. 
Choay, F. (2009). Le Patrimoine en questions, sous-titré Anthologie pour un combat. Paris: Seuil.

Ciolan, L. (2008). Invăţarea integrată. Fundamente pentru un curriculum transdisciplinar. Iaşi: Editura Polirom.

Davallon, J. (2010). The Game of Heritagization. pp. 3962. In Constructing Cultural and Natural Heritage: Parks, Museums and Rural Heritage. Xavier Roigé \& Joan Frigolé, (Eds.) Girona: Institut Català de Recerca en Patrimoni Cultural.

Dewey, J. (1963). Experience and education. New York: Collier Books.

Friedman, T.L. (1999). The Lexus and the olive tree. New York: Farrar, Straus, Giroux.

Garcia, H.E. (2020). Optimizing Globalization Will Become Possible with a New Paradigm. In Interdisciplinary Journal of Partnership Studies, Vol.7, No.1. Available at: https://pubs.lib.umn.edu/index.php/ijps/article/view/30 29 (accessed at 1.02.2021).

Gibbons, M. et al. (1994). The New Production of Knowledge: The Dynamics of Science and Research in Contemporary Societies. London: Sage Publication Ltd. Available https://www.researchgate.net/publication/225088790_T he_New_Production_of_Knowledge_The_Dymics_of_ Science_and_Research_in_Contemporary_Societies (accessed at 2.11. 2020).

Glava, A.-E., \& Glava, C.C. (2011). The model and the didactic modelling an analytic point of view. Procedia Social and Behavioral Sciences, 15, 2228-2231, 2011. London: Elsevier. Available at: https://www.sciencedirect.com/science/article/pii/S187 7042811006306 (accessed at 7.11. 2020).

Glava, C.C. (2009). Formarea competenţelor didactice prin intermediul e-learning: modele teoretice şi aplicative. Cluj-Napoca: Casa Cărţii de Ştiinţă.

Hall, E.T. \& Hall M.R. (1990). Understanding cultural differences: Germans French and Americans, ME: Intercultural Press, Yarmouth.

Hattie, J. (2009). Visible Learning: A Synthesis of Over 800 Meta-Analyses Relating to Achievement. London: Routledge.

Ionescu, M. (2010). Şcoala clujeană de pedagogie după înfiinţarea universităţii româneşti şi principalele direcţii de studiu şi acţiune - Abordare diacronică. In Ionescu, M. (Ed.) Şcoala clujeană de pedagogie - 90 de ani. Cluj-Napoca: Casa Cărţii de Ştiinţă.

Ionescu, M. \& Chiş, V. (2001). Metodologia activităţii didactice între rutină şi creativitate. In M. Ionescu \& I.
Radu (Eds.). Didactica modernă. Ediția a II-a, revizuită. Cluj-Napoca: Editura Dacia.

Jeannin, L. (2017). The adaptation process of international lecturers in a South African university: The centrality of agency and collegiality. Journal of Research in International Education, SAGE Publications, 2017, 16 (3), pp. 236-247. Available at: ff10.1177/1475240917746035ff. ffhal-01892135f (accessed at 10.09.2020).

Meirieu, P. \& Develay, M. (1992). Émile, reviens vite... Ils sont devenus fous. Paris: ESF.

Mezirov, (2012). Transformative Dimensions of Adult Learning. 1st Edition. Los Angeles: The Jossey Education Series.

Mizzi R.C., Rocco, T. \& Shoe S. (Eds.) (2017). Disrupting Adult and Community Education: Teaching, Learning, and Working in the Periphery. Albany: State University of New York Press.

Morin, E. (1999). Relier les connaissances. Le défi du XXIe siècle. Paris: Seuil.

Negruţiu, S. (2005). Valorificarea folclorului în invăţământul primar: scenarii educaţionale. ClujNapoca: Casa Cărţii de Ştiinţă.

Nicolescu, B. (1985) Nous, la particule et le monde. Paris: Éditions Le Mail.

Nicolescu, B. (1996). La transdisciplinarité (manifeste). Monaco: Éditions du Rocher.

Nicolescu, B. (2012). The Transdisciplinary Evolution of the University Condition for Sustainable Development. CIRET Centre International de Recherches et études Transdisciplinaires. Paris. Available at: http://cirettransdisciplinarity.org/bulletin/b12c8.php (accessed at 15.10.2020).

Păun, E. (1999). Şcoala, abordare sociopedagogică. Iaşi: Polirom.

Păun, E. (2017). Pedagogie - Provocări şi dileme privind şcoala şi profesia didactică. Iaşi: Editura Polirom.

Schwab, K. (2015). The Fourth Industrial Revolution. What It Means and how to Respond. Foreing Affairs. Available at https://www.foreignaffairs.com/ articles/2015-12-12/fourth-industrial-revolution (accessed at 17.10.2020).

Somé, R. (2004). Le musée à l'ère de la mondialisation. Pour une anthropologie de l'altérité. Paris: L'Harmattan.

Somé, R. (2017). Anthropologie et philosophie du sensible. Saint-Denis: Connaissances et savoirs.

Somé, R. (2019). Support de cours 2019. Anthropologie de l'art. Université de Strasbourg. 
Somé, R. \& Le Roux, P. (2017). Sociétés et êtres d'exception. Approche interdisciplinaire et des sciences participatives. In Séminaire «Ethnologie et archéologies». Université de Strasbourg. Available at: file:///F:/Articol\%20Roger\%20Some.pdf (accessed at 25.01. 2020).

Steffen, W., Crutzen, P. \& McNeill, J. (2007). The Anthropocene: Are Humans Now Overwhelming the Great Forces of Nature? AMBIO: A Journal of the Human Environment, 36(8), 614-621.Available at: https://pubmed.ncbi.nlm.nih.gov/18240674/ (accessed at 12.02.2021).

Sterling, S. (2001). Sustainable Education: Re-visioning Learning and Change. London: Edition Green Books.

Twining, P., Butler, D., Fisser, P., Leahy, M., Shelton, C., Forget-Dubois, N., \& Lacasse, M. (2020). Developing a quality curriculum in a technological era. Educational Technology Research and Development. Springer Nature Swizerland, 1-24. Available at: https://www.ncbi.nlm.nih.gov/pmc/articles/PMC76570 $67 /$ (accessed at 10.02.2021).
Văideanu, G. (1988). Educația la frontiera dintre milenii. București: Editura Politică.

Encyclopedia Britannica. (2007). London: Encyclopaedia Britannica, Inc.

International Commission on Education for the Twentyfirst Century. Delors, J., \& Unesco. (1996). Learning, the treasure within: Report to UNESCO of the International Commission on Education for the Twentyfirst Century. Paris: Unesco Pub.

OCED. (2020). The OECD Future of Education and Skills 2030. Conceptual Learning Framework - The Learning Compass 2030. Available at: https://www.oecd.org/education/2030-project/teachingand-learning/learning/ (accessed at 03/02/2021).

UNESCO. (2003). Text of the Convention for the Safeguarding of the Intangible Cultural Heritage. Available at: https://ich.unesco.org/en/convention (accessed at 15.10.2020). 